\title{
THE ROLE OF THE UK
}

IN TACKLING

GLOBAL INEQUALITY

Contributions to achieving SDG 10 
This year, the UN High-Level Political Forum on Sustainable Development is assessing global efforts in achieving Goal 10 (reducing inequality) and the UK government is reviewing its progress towards the SDGs. While the UK government has adopted some policies that can contribute to achieving Goal 10 globally, it is failing to prioritize the actions needed to reduce inequality between and within countries, lacking policy coherence, especially in taxation and international development.

In 2020, the SDG 'decade of delivery' will commence. This paper examines how the UK government can resume the leadership role that it played in the design of the 2030 Agenda, starting with the recognition that achieving Goal 10 is essential to its realization. It makes recommendations for how UK aid can be used to tackle extreme poverty and inequality globally.

\section{(C) Oxfam GB June 2019}

This paper was written by Chiara Mariotti. Oxfam acknowledges the assistance of Gideon Rabinowitz, Claire Spoors, Oli Pearce, Francesca Rhodes and Anna Marriott in its production. It is part of a series of papers written to inform public debate on development and humanitarian policy issues.

For further information on the issues raised in this paper please email advocacy@oxfaminternational.org

This publication is copyright but the text may be used free of charge for the purposes of advocacy, campaigning, education, and research, provided that the source is acknowledged in full. The copyright holder requests that all such use be registered with them for impact assessment purposes. For copying in any other circumstances, or for re-use in other publications, or for translation or adaptation, permission must be secured and a fee may be charged. Email policyandpractice@oxfam.org.uk

The information in this publication is correct at the time of going to press.

Published by Oxfam GB under ISBN 978-1-78748-446-7 in June 2019.

DOI: $10.21201 / 2019.4467$

Oxfam GB, Oxfam House, John Smith Drive, Cowley, Oxford, OX4 2JY, UK. 
In 2015, the UK government played a leading role in setting the 2030 Agenda for Sustainable Development and rooting it in the principle of 'Leave No One Behind' (LNOB). According to this principle, absolute poverty must be ended by prioritizing and fast-tracking action for the people and countries already the furthest behind. An innovative feature of the 2030 Agenda is the inclusion of Goal 10: 'reduce inequality within and among countries'. This Goal reflects the widespread recognition that inequality is one of the critical challenges of our times $^{1}$ and that each country carries responsibility for tackling extreme economic inequality, both at home and globally. Inequality is bad for economic growth, ${ }^{2}$ undermines a country's social contract, fosters instability and violence and hampers progress on health. ${ }^{3}$ It is also a major obstacle to addressing the other great challenges identified in the 2030 Agenda, including gender inequality, climate change, the crisis of democracy and work-displacing technological progress. Following the adoption of the Sustainable Development Goals (SDGs), global development efforts should be seeking to tackle extreme inequality as well as poverty, together with the other major global challenges to development.

Four years after the adoption of the 2030 Agenda, the inequality crisis continues unabated. This year, the UK government is reviewing its progress towards the SDGs, and the UN High-Level Political Forum on Sustainable Development (HLPF) is assessing global efforts in achieving Goal 10. This brief offers an overview of the latest trends in global inequality and in Goal 10, and the extent to which UK aid has contributed to them.

\section{A REVIEW OF GLOBAL PROGRESS IN ACHIEVING GOAL 10}

\section{Extreme economic inequality is on the rise. This undermines poverty eradication and worsens climate change.}

Recent World Bank estimates show that according to current economic growth predictions - and if the present levels of inequality remain unchanged - in 2030 about $6.5 \%$ of the global population will still be living in extreme poverty (on less than $\$ 1.90$ a day). ${ }^{4}$ Tackling inequality - reducing each country's Gini index by $1 \%$ per year, would reduce extreme poverty more than increasing each country's annual growth rate by one percentage point above forecasts. ${ }^{5}$ In other words, reducing inequality would be more effective at eradicating poverty than increasing economic growth. 
The pace of global poverty reduction halved between 2013 and 2015, and the number of people living in extreme poverty in sub-Saharan Africa has increased, from 278 million in 1990 to 413 million in $2015 .{ }^{6}$ This contrasts with the steady accumulation of wealth at the top: in 2018 alone, the wealth of the world's 1,900 billionaires increased by $\$ 2.5$ bn each day. ${ }^{7}$ Achieving Goal 10 through more equitable economic systems is also necessary to combat climate change (Goal 13), given that the poorest half of the global population is responsible for only around $10 \%$ of total global emissions, while the richest $10 \%$ are responsible for around $50 \%{ }^{8}$

\section{We are not on track to achieve Goal 10 globally.}

Global progress on Goal 10, as measured by Target 10.1 ('By 2030, progressively achieve and sustain income growth of the bottom $40 \%$ of the population at a rate higher than the national average') has been weak. According to the World Bank, for 91 countries with available data, only 51 saw the income or consumption of the bottom $40 \%$ grow faster than the average (between around 2010 and 2015), and in most cases growth was only marginal. ${ }^{9}$ In all other countries, growth was slower for the bottom $40 \%$, suggesting a worsening in the distribution of wealth. Data are available for only a quarter of low-income economies: for example, only 12 of 45 sub-Saharan African countries are included and there are no data for India or Nigeria, the two countries with the largest number of extremely poor people in the world. ${ }^{10}$ This means that we know little about progress at the very bottom of the distribution.

\section{The existing indicator framework for Goal 10 is not sufficient to capture important aspects of the evolution of economic inequality.}

Inequality concerns those left behind as well as runaway wealth and incomes at the top of the distribution. However, Goal 10 has no indicator to capture the concentration of income or wealth at the top and it also fails to capture other important dimensions of economic inequality.

For example, Target 10.1 only measures mean income growth and it only compares the bottom $40 \%$ with the average, instead of comparing the tails of the distribution. This means that the indicator would fail to capture a decline in the income share of the bottom $40 \%$ to the advantage of the top of the distribution, or a better performance of the bottom $40 \%$ due to average negative income growth. ${ }^{11}$ The indicator is also of little help in applying the LNOB principle: it provides little information on the extent to which the poorest people are capturing the benefits of economic growth, because the bottom $40 \%$ represents a very heterogeneous group that includes different proportions of poor people in different countries. We know even less about how well the most vulnerable groups - including women, ethnic minorities and people with disabilities - are actually doing, compared with the rest of the distribution.

Target 10.4 ('Adopt policies, especially fiscal, wage and social protection policies, and progressively achieve greater equality') has just one indicator 
(labour share of GDP), which captures only one desired outcome of greater equality and misses, for example, the redistributive impact of fiscal policies.

\section{Accelerating progress on Goal 10 requires a comprehensive monitoring framework which includes indicators that compare the tails of the distribution and capture the impact of redistributive policies.}

This would include complementing Target 10.1 and Target 10.4 with the following indicators:

- the Palma ratio ${ }^{12}$ (which compares the income of the bottom $40 \%$ of the population with that of the top $10 \%$ );

- the post-tax income of the top $10 \%$, the top $1 \%$ and the top $0.1 \%$ and the post-transfer income of the bottom $40 \%$, as well as indicators of wealth concentration;

- the difference between the Gini coefficient of the income distribution before and after taxes and transfers, according to the methodology developed by Commitment to Equity. ${ }^{13}$

In addition, to ensure that inequality is reduced in a way that is consistent with the LNOB principle, there is a need for better and more disaggregated data that can capture the intersection between economic inequality and inequality due to discrimination based on gender, ethnic background, religious affiliation or disability.

The UK government has been a leader in recognizing that better and more disaggregated data are at the core of progress on development and the fight against poverty, signing up to the Inclusive Data Charter in 2018. ${ }^{14}$ The Charter aims to ensure that no one is left behind in the pursuit and measurement of social and economic progress, and DFID has committed to building capacities for data disaggregation in other countries.

\section{Recommendations for the UK government:}

- Going forward, the government should demonstrate leadership in recognizing that monitoring progress on reducing inequality requires indicators that measure the gap between rich and poor, comparing the tails of the distribution and capturing the impact of redistributive policies.

- To this end, during the 2020 Comprehensive Review of the global indicators framework led by the Inter-Agency and Expert Group on SDG Indicators (IAEG-SDGs), ${ }^{15}$ the government should advocate for the introduction of two new indicators for Goal 10: the Palma ratio for Target 10.1 and the difference between the Gini coefficient of the income distribution before and after taxes and transfers for Target 10.4 . 


\section{THE UK'S CONTRIBUTION TO ACHIEVING GOAL 10}

The UK government has taken action in some policy areas that can contribute to achieving Goal 10 globally, but overall it is not showing clear commitment to this part of the agenda. It is failing to prioritize the actions needed to reduce inequality between and within countries; it lacks policy coherence between domestic and international policies, especially in the area of taxation; and it is also adopting approaches in its international development strategy that risk undermining progress towards achieving the goal.

\section{Aid flows (Targets 10.1 and $10 . b^{16}$ )}

Based on the limited available data, only a minority of countries receiving UK official development assistance (ODA) are performing well on Target 10.1 and are therefore achieving inclusive growth. Data for Target 10.1 exist for 56 of the 135 countries that received UK bilateral aid in 2017. Of these 56 countries, only 34 saw income (or consumption) grow faster for the bottom $40 \%$ of the population than the average. ${ }^{17}$ However, this did not happen in any of the top 20 country recipients of UK bilateral ODA in 2017 for which data are available, where instead growth in income (or consumption) for the bottom $40 \%$ was positive, but lower than the average growth. This means that economic growth was accompanied by an increase in inequality, as reflected in their high Gini coefficient (see Appendix 1). UK aid to these countries needs to be reconfigured to tackle inequality more specifically if it is to achieve inclusive growth and contribute to achieving Goal 10.

The contribution of UK aid to achieving Target 10.b is mixed. On the one hand, the majority of DFID's bilateral aid targets Least Developed Countries (LDCs) and other Low-Income Countries (LICs): it was $65.5 \%$ in 2017 , up from $59.3 \%$ in 2016. ${ }^{18}$ On the other hand, aid delivered outside of DFID has trebled in volume (to $£ 3.8 \mathrm{bn}$, or $25 \%$ of the UK aid budget). Non-DFID aid is mostly focused on addressing the UK's security, diplomatic and economic interests, rather than tackling poverty and inequality, and tends to favour middle-income countries. In fact, the share of this non-DFID aid delivered to LDCs and other LICs has halved, from $55.1 \%$ in 2011 to $25.2 \%$ in $2017 .{ }^{19}$

At the same time, aid to a number of countries which have recently graduated to middle-income status but still face significant vulnerabilities (e.g. Ghana, Vietnam, Cambodia), and which in some cases host large numbers of extremely poor people, has been declining, and is less targeted at the poorest people. This is most striking in the case of India, which received $£ 249 \mathrm{~m}$ of UK aid in 2013 but only $£ 90 \mathrm{~m}$ in 2017 , despite being home to more than 170 million people living in extreme poverty. ${ }^{20}$

\section{Recommendations for the UK government:}

- To ensure that it contributes to achieving Goal 10 as well as eradicating extreme poverty, the government should continue to direct the majority of 
UK aid to LDCs and LICs, without neglecting MICs with large numbers of poor people.

- It should rethink UK aid and the country's foreign policy more generally, so that it contributes to tackling extreme inequality as well as poverty following the example of the World Bank, which in 2013 adopted two new goals to guide its work: ending extreme poverty and boosting shared prosperity. ${ }^{21}$

- In practice, the government should encourage recipient countries to set clear targeted plans to reduce the gap between rich and poor, expressed in terms of the Palma ratio, and assess progress in terms of the extent to which the incomes of the poorest people grow compared with those in the top $10 \%$.

\section{GENDER INEQUALITY AND THE LNOB AGENDA}

Persistent gender inequality is a major barrier to reducing economic inequality and achieving Goal 10, while people disadvantaged due to factors such as their gender, age, ethnicity or religion are more likely to be left behind. This is especially recognized in Targets 10.2 and $10.3,{ }^{22}$ and it implies that to make progress on Target 10.1 and achieve Goal 10, it is necessary to address the intersecting inequalities that the bottom $40 \%$ experience and the ways that economic inequality is inextricably linked to gender inequality.

DFID's Strategic Vision for Gender Equality: A Call to Action for Her Potential, Our Future is an important recognition of the centrality of gender equality to the whole SDGs agenda. ${ }^{23}$ However, efforts to address the structural causes of gender inequality need to be taken up throughout DFID's work if they are to be effective.

DFID's Economic Development Strategy commits to 'place the economic empowerment of girls and women at the heart of [its] approach' and to 'leave no one behind', which is a welcome recognition of the need to address gender and other inequalities. ${ }^{24}$ However, the Strategy needs to be clearer and stronger as to how it will address structural gender inequality in the economy. For example, the heavy and unequal responsibility that women bear for unpaid care and domestic work is mentioned in the Strategy, but using investments in social and physical infrastructure in a strategic way to reduce and redistribute this work is not.

In terms of funding, less than $46 \%$ of UK aid has gender equality as a secondary or primary objective. ${ }^{25}$ Women's rights activism and movements are the catalysts for legal and policy change to address gender inequality, ${ }^{26}$ but they receive very little support from governments and donors. In 2016-17, OECD countries committed only $\$ 177 \mathrm{~m}$ overall to non-governmental women's organizations and even less - $\$ 31 \mathrm{~m}$ - to those based in developing countries, down from $\$ 225 \mathrm{~m}$ and $\$ 38 \mathrm{~m}$ respectively in the previous year. ${ }^{27}$

\section{Recommendations for the UK government:}

- Using country diagnostics and consultations with women, DFID should prioritize investment in social and physical infrastructure used by women 
and support gender-responsive public services more generally, for example by increasing the provision of water, electricity and child and social care.

- The UK government should scale up support to women's rights organizations through more partnerships and dedicated investment, operating according to feminist principles through learning, collaboration, participation, inclusivity and responsiveness.

\section{Fiscal policies and domestic resource mobilization (Target 10.4)}

There is strong international evidence that progressive action by governments through fiscal, wage and social protection policies is effective in tackling economic inequality ${ }^{28}$ - policies that are also possible in low- and middleincome countries. ${ }^{29}$ Domestic resource mobilization (DRM), a cornerstone of any progressive fiscal policy, has been at the top of the international development agenda since the Financing for Development Conference in Addis Ababa in 2015 focused on securing sufficient funds to achieve the SDGs.

The Addis Tax Initiative (ATI) requires donors to make three commitments: to double support for DRM; to step up DRM in order to deliver the SDGs; and to pursue policy coherence in relation to DRM, including minimizing their own negative policy spillover, for instance by reviewing tax treaties and promoting global tax transparency rules. ${ }^{30}$ The UK government has been a champion of the ATI, but although it committed to double its spending on improving tax systems in the Global South by 2020 from a 2014 baseline of $£ 25 \mathrm{~m}$ per year, by 2017 this spend had reached only $£ 27 \mathrm{~m} .{ }^{31} \mathrm{~A}$ significant improvement would be the implementation of the $£ 47 \mathrm{~m}$ package of support for improving tax systems in developing countries announced in February 2019. ${ }^{32}$

Tackling corporate and individual tax dodging is equally critical to achieving Goal 10 both nationally and globally, because it helps to ensure that developing country governments are not deprived of scarce tax revenues needed to pay for making public services more equal. The IMF recently estimated that non-OECD countries lose about \$200bn in revenue every year, or about $1.3 \%$ of GDP, due to companies shifting profits to low-tax locations. ${ }^{33}$

The UK has positioned itself as a global leader on international tax transparency and anti-corruption since its presidency of the G8 in 2013, for example signing up to the Extractives Industries Transparency Initiative (EITI) and creating a central public register containing details of the beneficial ownership of UK companies. The UK government introduced legislation through the Finance Act 2016 allowing for the introduction of public country-bycountry reporting requirements for multinational companies regarding their tax affairs. This measure could substantially help tax authorities, including in the Global South, to collect more of the taxes they are due. However, the UK has not yet implemented this power, claiming that it is seeking a multilateral agreement first. An amendment to the Anti Money-Laundering Act 2018 required the UK's Overseas Territories to introduce public registers of beneficial ownership by the end of 2020 . However, the government has recently allowed an extension of the deadline for introducing this transparency measure to $2023 .^{34}$ 


\section{Recommendations for the UK government:}

- Leading by example, the government should implement tax reforms that would contribute to fairer and more sustainable tax systems, both domestically and globally. This includes implementing measures in the Finance Act 2016 allowing for the introduction of public country-by-country reporting requirements for multinational companies, and ensuring that the Sanctions and Anti-Money Laundering Act 2018 requirement for the public register of beneficial ownership in the UK Overseas Territories is implemented, including an equivalent for Crown Dependencies (Jersey, Guernsey and the Isle of Man), should they not introduce public registers voluntarily as they have recently committed to doing.

- The government should meet the commitment to allocate aid to DRM taken through the ATI, and promote the inclusion of all countries on an equal footing in the second round of BEPS international tax reform negotiations. It should also ensure that the UK's tax policies support and do not undermine the potential for countries in the Global South to set their own tax policies and collect tax revenues.

The UK government has been less clear in its commitment to policy changes that would halt the 'race to the bottom' on corporate income tax rates. Since countries in the Global South rely relatively more heavily than developed countries on corporate tax revenues, they have an even greater interest in ensuring that this trend is reversed. The UK also played a key role in the first international tax reform process led by the OECD - known as the base erosion and profit shifting, or BEPS, process. The latest round of proposals to address corporate tax avoidance presented by the OECD includes options - such as a minimum effective tax rate - which could have a powerful positive impact.

\section{Recommendations for the UK government:}

- The government should engage positively in international negotiations to avoid a race to the bottom on corporate tax rates, in order to support ambitious and effective global rules.

The UK's tax system can tackle economic inequality at home as well as overseas. Taxes on wealth in the UK are patchy, with incentives for richer people to receive more of their income as capital gains than as wages, as the tax rates are lower. ${ }^{35}$ Since inequality of wealth, in the UK as well as globally, is more pronounced than income inequality, ${ }^{36}$ in most countries it is possible to raise more revenue and make the tax system more progressive by reforming existing wealth taxes. In the UK, options could include overhauling council tax, equalizing the rates on capital gains and income tax and implementing a net wealth tax. ${ }^{37}$

\section{Recommendations for the UK government:}

- Review UK wealth taxes and introduce reforms to make them more progressive and to raise significant revenues that could be used to finance progress on the SDGs at home and globally. 


\section{Social spending and universal access to health and education}

Good-quality, gender-responsive and universal public services free at the point of use and universal social protection are powerful tools available to governments to achieve Goal 10. The IMF has acknowledged that spending on health and education plays a critical role in redistributing income and enabling more equitable economic growth, making it easier for poor people to capture its benefits. ${ }^{38}$ For example, research shows that in the low-income countries that are doing the most to prevent poor women from dying in child-birth, $90 \%$ of the care is provided by the public sector and in every case the private sector plays a negligible role. ${ }^{39}$

Aid remains essential to support public services in developing countries whose economies are not yet strong enough to generate sufficient revenues. ${ }^{40}$ However, in recent years the share of UK aid for health and education has been falling. Following significant increases during 2010-13, over the period 2014-17 the share of UK bilateral aid focused on education and health fell from 17.7 to $12.4 \%$ and from 24.8 to $20.4 \%$, respectively. ${ }^{41}$

The UK government is also channeling an increasing amount of funds for social spending through the CDC Group (formerly the Commonwealth Development Corporation). The CDC typically supports health and education programmes where fees are charged for pupils and patients, for example requiring direct payments or private insurance for people to access healthcare delivery. There are concerns that this modality of delivery may have negative impacts on poverty and inequality and may undermine progress on the SDGs. In fact, evidence shows ${ }^{42}$ that fees for public services like healthcare and education result in hospitals or schools that are unaffordable for most, which contradicts Target 4.1 (ensure free primary and secondary education for all girls and boys) and Target 3.8 (guarantee universal health coverage).

\section{Recommendations for the UK government:}

- In its aid programmes, the government should prioritize financing and championing the crucial role that publicly financed, gender-responsive and universal healthcare, education and social protection, delivered free of charge, play in reducing inequality. This includes supporting countries to remove user fees and build social protection floors. It should support the strengthening and expansion of public services through long-term, predictable, coordinated and, where possible, on-budget aid.

- It should also put in place further measures to ensure that the work of DFID and the CDC does not exacerbate inequality through profit-making interventions in public services in the Global South.

The UK has supported global efforts to increase access to medicines, vaccines and diagnostics for specific diseases relevant to developing countries, especially via its support of GAVI (formerly the Global Alliance for Vaccines and Immunization), the Global Fund and Unitaid. However, in the recent negotiations for a landmark World Health Assembly resolution to increase transparency of pricing for both research and development and the resulting medicines, the UK government exerted its influence to significantly dilute the 
language and intent of the resolution, and then formally disassociated itself from it at the point of its adoption. ${ }^{43}$

\section{Recommendations for the UK government:}

- The UK should reverse its decision on this resolution and should demonstrate its commitment to supporting actions to reduce the price of medicines, vaccines and diagnostics.

\section{IMPROVE THE UK'S IMPLEMENTATION OF THE SDGS}

In 2020, the SDG 'decade of delivery' will commence. The UK government should resume the leadership role that it played in 2015 in the design and adoption of the 2030 Agenda, starting with the recognition that achieving Goal 10 is essential to realize the whole of the Agenda, and chiefly to tackle extreme poverty.

\section{Recommendations for the UK government:}

- Adopt a cross-government strategy for delivering and monitoring the SDGs, one that recognizes that the Goals are interconnected and ensures coherence between domestic policies, the international development agenda and other international commitments. 


\section{APPENDIX 1: GOAL 10 - INDICATORS \\ OF INEQUALITY IN THE TOP 20 \\ COUNTRY RECIPIENTS OF UK \\ BILATERAL AID}

\begin{tabular}{|c|c|c|c|c|c|}
\hline $\begin{array}{l}\text { Top } 20 \text { country } \\
\text { recipients of UK } \\
\text { bilateral ODA in } \\
2017^{44}\end{array}$ & $\begin{array}{l}\text { Shared } \\
\text { prosperity* } \\
\text { (circa 2011- } \\
2016)^{45}\end{array}$ & $\begin{array}{l}\text { Shared } \\
\text { prosperity } \\
\text { premium } \\
\text { (circa } 2011-^{\text {2016) }}\end{array}$ & $\begin{array}{l}\text { Headcount } \\
\text { poverty ratio at } \\
\$ 1.90 \text { poverty } \\
\text { line }^{47}\end{array}$ & $\begin{array}{l}\text { Gini } \\
\text { coefficient }^{48}\end{array}$ & Year*** \\
\hline Pakistan & 2.72 & -1.53 & 3.94 & 33.45 & 2016 \\
\hline Nigeria & $\mathrm{N} / \mathrm{A}$ & $\mathrm{N} / \mathrm{A}$ & 53.47 & 42.97 & 2010 \\
\hline Ethiopia & 1.46 & -3.23 & 27.34 & 39.07 & 2016 \\
\hline Syria & $\mathrm{N} / \mathrm{A}$ & $\mathrm{N} / \mathrm{A}$ & 1.67 & 35.78 & 2004 \\
\hline Somalia & N/A & $\mathrm{N} / \mathrm{A}$ & $N / A$ & N/A & $N / A$ \\
\hline Afghanistan & N/A & $\mathrm{N} / \mathrm{A}$ & $N / A$ & N/A & $N / A$ \\
\hline Yemen & N/A & $\mathrm{N} / \mathrm{A}$ & $\mathrm{N} / \mathrm{A}$ & N/A & N/A \\
\hline Bangladesh & 1.35 & -0.19 & 14.77 & 32.39 & 2016 \\
\hline South Sudan & N/A & $\mathrm{N} / \mathrm{A}$ & 42.71 & 46.34 & 2009 \\
\hline Tanzania & $\mathrm{N} / \mathrm{A}$ & $\mathrm{N} / \mathrm{A}$ & 49.09 & 37.78 & 2012 \\
\hline $\begin{array}{l}\text { Democratic } \\
\text { Republic of the } \\
\text { Congo }\end{array}$ & $\mathrm{N} / \mathrm{A}$ & $\# \mathrm{~N} / \mathrm{A}$ & 76.59 & 42.1 & 2012 \\
\hline Kenya & $\mathrm{N} / \mathrm{A}$ & $\mathrm{N} / \mathrm{A}$ & 36.83 & 40.78 & 2016 \\
\hline Uganda & -2.20 & -1.19 & 41.66 & 42.75 & 2017 \\
\hline Turkey & 2.53 & -0.94 & 0.23 & 41.87 & 2016 \\
\hline Burma [Myanmar] & $\mathrm{N} / \mathrm{A}$ & $N / A$ & 6.22 & 38.07 & 2015 \\
\hline Sierra Leone & $\mathrm{N} / \mathrm{A}$ & N/A & 52.21 & 34.03 & 2011 \\
\hline Lebanon & $\mathrm{N} / \mathrm{A}$ & $\mathrm{N} / \mathrm{A}$ & 0 & 31.83 & 2012 \\
\hline Nepal & $\mathrm{N} / \mathrm{A}$ & $\mathrm{N} / \mathrm{A}$ & 14.99 & 32.84 & 2010 \\
\hline Zimbabwe & $\mathrm{N} / \mathrm{A}$ & $N / A$ & 21.4 & 43.15 & 2011 \\
\hline India & $\mathrm{N} / \mathrm{A}$ & $\mathrm{N} / \mathrm{A}$ & 21.23 & 35.71 & 2012 \\
\hline
\end{tabular}

*Shared prosperity: annualized growth in mean consumption or income per capita of the bottom $40 \%$.

${ }^{* *}$ Shared prosperity premium: difference in consumption or income growth of the bottom $40 \%$ and that of the total population.

${ }^{* * \star}$ Year applies to Headcount Ratio and Gini index. 
1 World Economic Forum (2017). The Global Risks Report 2017. Geneva: WEF. http://www3.weforum.org/docs/GRR17 Report web.pdf

2 A. Berg and J.D. Ostry (2011). Inequality and Unsustainable Growth: Two Sides of the Same Coin? IMF Staff Discussion Note 11/08. Washington, DC: International Monetary Fund. https://www.imf.org/external/pubs/ft/sdn/2011/sdn1108.pdf

3 R. Wilkinson and K. Pickett (2010). The Spirit Level: Why Greater Equality Makes Societies Stronger. New York: Bloomsbury Press.

4 C. Lakner, et al. (2019). How Much Does Reducing Inequality Matter for Global Poverty? Poverty and Equity Global Practice Working Paper Series; no. 205. Washington, D.C. World Bank Group. http://documents.worldbank.org/curated/en/739221559589341838/How-MuchDoes-Reducing-Inequality-Matter-for-Global-Poverty

5 lbid.

6 World Bank (2018). Poverty and Shared Prosperity 2018: Piecing Together the Poverty Puzzle. Washington, DC: World Bank. License: Creative Commons Attribution CC BY 3.0 IGO.

https://openknowledge.worldbank.org/bitstream/handle/10986/30418/9781464813306.pdf

7 M. Lawson, et al. (2019). Public Good or Private Wealth? Oxfam Briefing Paper: Davos Report 2019. https://www.oxfam.org/en/research/public-good-or-private-wealth. DOI: http://dx.doi.org/10.21201/2019.3651

8 T. Gore (2015). Extreme Carbon Inequality: Why the Paris climate deal must put the poorest, lowest emitting and most vulnerable people first. Oxfam. https://policypractice.oxfam.org.uk/publications/extreme-carbon-inequality-why-the-paris-climate-dealmust-put-the-poorest-lowes-582545.

9 World Bank (2018). Poverty and Shared Prosperity 2018, op. cit. Table 2.1

10 lbid.

11 N. Galasso (2015). The World Bank is Getting 'Shared Prosperity' Wrong: The Bank Should Measure the Tails, Not the Average. Global Policy. Volume 6, Issue 3, pp 321-324. University of Durham and Wiley. DOI: https://doi.org/10.1111/1758-5899.12240

12 For a discussion of the advantages of using the Palma ratio to measure inequality see: $\mathrm{M}$. Doyle and J. Stiglitz (2014). Eliminating Extreme Inequality: A Sustainable Development Goal, 2015-2030. Ethics \& International Affairs.

http://www.ethicsandinternationalaffairs.org/2014/eliminating-extreme-inequality-a-sustainabledevelopment-goal-2015-2030/; and A. Cobham and A. Sumner (2013). Is It All About The Tails? The Palma Measure of Income Inequality. CGD Working Paper 343. Washington, DC: Center for Global Development. http://www.cgdev.org/sites/default/files/it-all-about-tails-palmameasure-income-inequality.pdf

13 Commitment to Equity Institute. Tulane University. http://commitmentoequity.org/

14 Inclusive Data Charter. Everybody Counts. http://www.data4sdgs.org/sites/default/files/2018$\underline{08 / \text { IDC onepager Final.pdf }}$

15 See: UN. IAEG-SDGs. 2020 Comprehensive Review. https://unstats.un.org/sdgs/iaegsdgs/2020-comp-rev/

16 Target 10.b: 'Encourage official development assistance and financial flows, including foreign direct investment, to States where the need is greatest, in particular least developed countries, African countries, small island developing States and landlocked developing countries, in accordance with their national plans and programmes.' See Sustainable Development Goals: SDG Indicators, Metadata Repository. https://unstats.un.org/sdgs/metadata?Text=\&Goal=10\&Target=10.b

17 These 34 countries were: Malawi, Rwanda, China, Colombia, Egypt, Brazil, Malaysia, Tunisia, Philippines, Thailand, Vietnam, Kyrgyz Republic, Peru, Kosovo, Argentina, Chile, Burkina Faso, Kazakhstan, Botswana, Panama, Georgia, Belarus, Costa Rica, Honduras, Bolivia, Mongolia, Uruguay, Paraguay, Ecuador, Dominican Republic, El Salvador, Moldova, Togo and Croatia. Based on the World Bank's Global Database of Shared Prosperity; data analysis available upon request: http://www.worldbank.org/en/topic/poverty/brief/globaldatabase-of-shared-prosperity 
18 DFID. (2017). Statistics on International Development 2017.

https://www.gov.uk/government/statistics/statistics-on-international-development2017; and DFID. (2018). Statistics on International Development: Final UK Aid Spend 2017. https://www.gov.uk/government/statistics/statistics-on-internationaldevelopment-final-uk-aid-spend-2017.

19 lbid.

20 World Bank (2018), op. cit.

21 World Bank. Inequality and Shared Prosperity: Overview. http://www.worldbank.org/en/topic/isp/overview

22 Target 10.2: 'By 2030, empower and promote the social, economic and political inclusion of all, irrespective of age, sex, disability, race, ethnicity, origin, religion or economic or other status.' Target 10.3: 'Ensure equal opportunity and reduce inequalities of outcome, including by eliminating discriminatory laws, policies and practices and promoting appropriate legislation, policies and action in this regard.'

23 DFID (2018). DFID Strategic Vision for Gender Equality: A Call to Action for Her Potential, Our Future. https://assets.publishing.service.gov.uk/government/uploads/system/uploads/attachm ent data/file/708116/Strategic-vision-gender-equality1.pdf

24 DFID (2017). Economic Development Strategy: prosperity, poverty and meeting global challenges. http://pubdocs.worldbank.org/en/822011487174249256/DFID-EconomicDevelopment-Strategy-2017.pdf

25 OECD (2019). Aid in Support of Gender Equality and Women's Empowerment. http://www.oecd.org/dac/stats/aidinsupportofgenderequalityandwomensempowerment $\underline{\mathrm{htm}}$

26 OECD (2016). Donor Support to Southern Women's Rights Organisations. OECD Findings. OECD DAC Network on Gender Equality (GenderNet). http://www.oecd.org/dac/gender-development/OECD-report-on-womens-rightsorganisations.pdf

27 OECD (2019). Aid in Support of Gender Equality and Women's Empowerment, op. cit; OECD (2018). Aid to gender equality and women's empowerment: An Overview. http://www.oecd.org/dac/gender-development/Aid-to-gender-overview-2018.pdf

28 J. Martinez-Vazquez, V. Vulovic and B. Moreno Dodson (2014). The Impact of Tax and Expenditure Policies on Income Distribution: Evidence from a Large Panel of Countries. Georgia State University.

https://scholarworks.gsu.edu/cgi/viewcontent.cgi?article=1036\&context=econ facpub; https://econpapers.repec.org/paper/tulceqwps/30.htm; http://www.oecd.org/social/init-together-why-less-inequality-benefits-all-9789264235120en.htm; https://www.imf.org/external/pubs/ft/fandd/2015/03/pdf/jaumotte.pdf

29 M. Lawson and M. Martin (2018). The Commitment to Reducing Inequality Index 2018. Development Finance International and Oxfam. https://policypractice.oxfam.org.uk/publications/the-commitment-to-reducing-inequality-index-2018a-global-ranking-of-government-620553

30 Addis Tax Initiative. https://www.addistaxinitiative.net/

31 DFID (2018). Annual Report and Accounts 2017-18, p.22.

https://assets.publishing.service.gov.uk/government/uploads/system/uploads/attachm ent data/file/750989/DFID-Annual-Report-Accounts-2017-18-amended-Oct18.pdf

32 DFID (2019). New UK support to help improve tax systems in developing countries. Press release, 19 February. https://www.gov.uk/government/news/new-uk-support-tohelp-improve-tax-systems-in-developing-countries

33 C. Lagarde (2019). Corporate Taxation in the Global Economy. IMFBlog. https://blogs.imf.org/2019/03/25/corporate-taxation-in-the-global-economy/

34 Hansard (2019). Registers of Beneficial Ownership of Companies. 22 January 2019. https://hansard.parliament.uk/commons/2019-01-22/debates/0746C0B8-9917-4E75B4F0-DCF5750F1510/RegistersOfBeneficialOwnershipOfCompanies 
35 C. Roberts, Blakeley G and Murphy L (2018). A Wealth of Difference: Reforming the taxation of wealth. IPPR. http://www.ippr.org/research/publications/a-wealth-ofdifference

36 ONS (2018). Wealth in Great Britain wave 5: 2014 to 2016.

https://www.ons.gov.uk/peoplepopulationandcommunity/personalandhouseholdfinanc es/incomeandwealth/bulletins/wealthingreatbritainwave5/2014to2016

37 Roberts et al (2018), op. cit.

38 IMF. (2017). Fiscal Monitor: Tackling Inequality, October 2017. Washington, DC: IMF. https://www.imf.org/en/Publications/FM/Issues/2017/10/05/fiscal-monitor-october$\underline{2017}$

39 M. Lawson, et al. (2019). Public good or private wealth? op. cit.

40 M. Manuel, H. Desai, E. Samman and M. Evans (2018). Financing the end of extreme poverty, p.33. Overseas Development Institute (ODI).

https://www.odi.org/sites/odi.org.uk/files/resource-documents/12411.pdf

41 See endnote 15.

42 See review of evidence in E. Seery and J. Seghers (2019). Hitting the Target: An agenda for aid in times of extreme inequality. Oxfam Briefing Paper. https://www.oxfam.org/en/research/hitting-target-agenda-aid-times-extremeinequality; Oxfam (2019, forthcoming). Leveller Up: How universal good quality public education is a crucial element in the fight against inequality; and Eurodad (2018). History RePPPeated: How Public Private Partnerships are Failing. https://eurodad.org/HistoryRePPPeated

43 L. Lamble. (2019, May 28). UK refuses to back 'game-changing' resolution on drug pricing. The Guardian. https://www.theguardian.com/globaldevelopment/2019/may/28/uk-refuses-to-back-game-changing-resolution-on-drugpricing

44 DFID. (2018). Statistics on International Development. Final UK Aid spend 2017, op. cit.

45 World Bank. Global Database of Shared Prosperity. Updated in March 2019, downloaded on 21 June 2019. http://www.worldbank.org/en/topic/poverty/brief/globaldatabase-of-shared-prosperity

46 lbid.

47 World Bank. Povcalnet database. Data downloaded on 21 June 2019. http://iresearch.worldbank.org/PovcalNet/povOnDemand.aspx

48 Ibid. 


\section{OXFAM}

Oxfam is an international confederation of 19 organizations networked together in more than 90 countries, as part of a global movement for change, to build a future free from the injustice of poverty. Please write to any of the agencies for further information, or visit www.oxfam.org

Oxfam America (www.oxfamamerica.org)

Oxfam Australia (www.oxfam.org.au)

Oxfam-in-Belgium (www.oxfamsol.be)

Oxfam Brasil (www.oxfam.org.br)

Oxfam Canada (www.oxfam.ca)

Oxfam France (www.oxfamfrance.org)

Oxfam Germany (www.oxfam.de)

Oxfam GB (www.oxfam.org.uk)

Oxfam Hong Kong (www.oxfam.org.hk)

Oxfam IBIS (Denmark) (www.oxfamibis.dk)

Observer:

KEDV (Oxfam Turkey)
Oxfam India (www.oxfamindia.org)

Oxfam Intermón (Spain) (www.oxfamintermon.org)

Oxfam Ireland (www.oxfamireland.org)

Oxfam Italy (www.oxfamitalia.org)

Oxfam Mexico (www.oxfammexico.org)

Oxfam New Zealand (www.oxfam.org.nz)

Oxfam Novib (Netherlands) (www.oxfamnovib.nl)

Oxfam Québec (www.oxfam.qc.ca)

Oxfam South Africa (www.oxfam.org.za) 